\title{
The International Ancient Egyptian Mummy Tissue Bank
}

\author{
Patricia I Lambert-Zazulak
}

KNH Centre for Biomedical Egyptology, University of Manchester,

Faculty of Life Sciences, Stopford Building, Oxford Road, Manchester, MI 3 9PT, United Kingdom

KEY WORDS: Mummy, Tissue Bank, Manchester,

Palaeoepidemiology, Schistosomiasis

\begin{abstract}
This paper will present an outline of the history and purpose of the setting up of the International Ancient Egyptian Mummy Tissue Bank at the University of Manchester. Initiated in the context of the worldwide Schistosomiasis Research Project, the Tissue Bank aims to locate ancient Egyptian human remains worldwide outside of Egypt. Where it is possible, and when permission can be granted, the Tissue Bank collects deposits of small samples of mummy tissue, in order that they may be available for use in appropriate scientific research projects. Non-destructive sampling techniques, including endoscopy, are applied in order to preserve the conservation of mummies and to handle and store human remains ethically. Research facilitated by the large numbers of samples deposited in the Tissue Bank includes the palaeoepidemiology of schistosomiasis and other diseases, as well as the study of lifestyle and cultural factors, including insights into medical practices and embalming techniques.
\end{abstract}

\section{Introduction}

The International Ancient Egyptian Mummy Tissue Bank is located at the University of Manchester, and is administered by the KNH Centre for Biomedical Egyptology. This paper will briefly outline the history and purpose of the Bank; factors affecting the availability of Egyptian mummy tissue for study; how the Tissue Bank project collects the mummy tissue, and how it operates as a research resource.

\section{Purpose of the Tissue Bank}

The Tissue Bank was first conceived of in 1996 in the context of the worldwide Schistosomiasis Research Project, which was collecting epidemiological data on schistosomiasis. It was considered that an attempt to elucidate the paleoepidemiological picture of the disease in the ancient Egyptian people would possibly provide valuable evidence to compare with the pattern of the disease's occurrence in their descendants today (LambertZazulak, Rutherford, and David, 2003). So a collaboration was set up between Medical Service Corporation International based in the USA (the organizers of the Schistosomiasis Research Project); the Egyptian Reference Diagnostic Centre of the Egyptian Organization for Biological and Vaccine Production (also known as VACSERA), and the Manchester Mummy Research Project (Contis and David, 1996).

The opportunity to conduct large population studies on ancient Egyptian human remains is rare, as there are few special circumstances that make the remains of large numbers of individuals available for study. The Tissue Bank was set up with the purpose of providing a central resource for such studies, initially focusing on schistosomiasis (Rutherford, 2000), but potentially moving on to other diseases such as malaria.

Historically, perhaps the largest population sample study was conducted almost a century ago by the anatomists Elliot Smith and Wood Jones on the remains of several thousand individuals in Nubia, which were being excavated before the raising of the High Dam at Aswan. Their work concentrated especially on osteometric studies and on the pathology apparent in the gross anatomy of both skeletal and mummified remains, and work on this scale clearly has great statistical significance (Elliot Smith and Wood Jones, 1910).

Today paleopathology has various new technologies in its remit, which can be applied to very small samples of material which have been obtained from large numbers of individuals. Also, embalming materials are frequently present with the mummy tissue, and so samples containing embalming materials can be selected for use in studies which contribute to our knowledge of the history of embalming. 


\section{Factors affecting the availablity of mummy tissues for study}

The availability of tissue is governed by a range of historical, cultural, scientific and ethical factors, which will briefly be considered in turn.

Firstly, the natural conditions of Egypt meant that potentially almost any tissue type and burial artifact, even food and floral offerings, could be preserved indefinitely in a desiccated state.

Artificial mummification techniques practiced in ancient Egypt means that vast numbers of bodies were intentionally preserved. The actions of the embalmers were applied within the context of the religious and medical beliefs of the time. This made use of contemporary materials, instruments and techniques which were specially developed for the purpose, and applied according to the funerary rituals. In the higher class mummies, especially during the New Kingdom, this involved excerebration and the removal of the lungs, liver, stomach and intestines which were separately treated and preserved in canopic packages or jars. This has resulted in the differential preservation of different parts of the body, and of the diseases identifiable in them. For example, intestinal parasites that are present in the lumen of the gut may be lost in this process, whilst those which burrow into the intestinal wall are more likely to be preserved.Also, brain tissue is more likely to be preserved in the unexcerebrated lower class Egyptian mummies, or in burials which occurred historically prior to or subsequent to the application of artificial mummification and tomb burial as a cultural practice.

Because of the ancient Egyptian religious philosophy of providing the deceased with the material means for survival in the afterlife, high class burials were the target of robbery in antiquity. The result is that such mummies can be found to be in a fragmentary condition. However, in cases where other items such as texts and personal burial goods are preserved with the remains, these may give valuable corroborative evidence to be viewed with the surviving paleopathological data.

In more recent history, the activities of commercial and antiquities dealers, and collectors, have impacted the original burials and the distribution of the archaeological remains. Mummies and their bandages have been turned into commodities for purposes ranging from medicine to fuel, fertilizer and paper (Aufderheide, 2003). The fashion for collecting Egyptian artifacts as part of the Grand Tour saw the removal of a large number of mummified heads, hands and feet as souvenirs; the placing of whole mummies in coffins and with artifacts which didn't originally belong to them, and also the manufacture of fake mummies, sometimes incorporating genuine ancient parts.

As collectible items, ancient Egyptian artifacts and human remains were transported to be displayed in both private cabinets of curiosities and in public museums (Curl, 1994). However, conditions of changing temperature and humidity often resulted in deterioration. Unwrapping parties held in grand houses contributed to the deterioration and many mummies were buried, burned, broken up or otherwise disposed of, particularly during the Victorian era. Conservation measures have historically contributed in various ways to the current condition of mummy tissue, such as the application of varnish by nineteenth century conservators to the surface of the body. Ethical considerations and conservation priorities today demand the preservation of the integrity of museum specimens, and therefore their examination by non-destructive technologies is highlighted.

\section{Collecting mummy tissues for the bank}

The first part of the task of setting up the Bank was to locate Egyptian mummies now outside of Egypt. This was done in the form of a survey sent out to some 8000 addresses worldwide, including to museums, universities, research institutes, learned societies and private schools. The response was extremely large, and much interest was expressed in considering granting permission for many mummies and mummy parts to be biopsied in order to deposit small samples of tissue with the Tissue Bank (Lambert-Zazulak, 2000).

It is very important that the tissue sampling procedures are carried out using virtually non-destructive techniques. This includes small scale anatomical dissection, for example of the severed area of an already separated body part; obtaining small samples from canopic jars; and the use of specialized endoscopic techniques (Aufderheide, 2003). The Manchester Mummy Project has developed the application of small diameter industrial endoscopes for the examination and sampling of uncontaminated tissue from within the body cavities of mummies, in conjunction with radiological study (Tapp, Stanworth and Wildsmith, 1984).

\section{The tissue bank as a research resource}

The Bank has so far collected deposits of over 1000 tissue samples, representing more than 500 individuals, from collections worldwide outside of Egypt. On application, tissue may be allocated for use in carefully selected and well defined scientific research projects. A central archive of this work can then be produced. In addition, the historical and medical documentation on mummies, which the Tissue Bank project collects as part of its research work, is itself a valuable academic resource. The project is continually seeking to locate and collect information on Egyptian mummies and mummy parts for this purpose, and where it is possible, and when permission can be granted, deposits of small samples of mummy tissue are accepted for the Tissue Bank.

\section{Conclusion}

The scientific and ethical context of today's mummy studies means that tissue banking can play a key role as part of the 
non-destructive scientific investigation of ancient human remains, and can make an important contribution to the ongoing study and conservation of mummified human remains in collections.

\section{Acknowledgements}

This work has been made possible by the generous support of the Leverhulme Trust, the North West Museum Service, the KNH Charitable Trust, the Manchester Museum and the Faculty of Life Sciences of the University of Manchester, and the many depositors of mummy tissue.

\section{Literature Cited}

Aufderheide A. 2003. The Scientific Study of Mummies. Cambridge: Cambridge University Press. P 385-388, and p 5 I5-524.

Contis G, and David AR. 1996. The epidemiology of Bilharzia in ancient Egypt: 5000 years of schistosomiasis. Parasitology Today 2(II): 253-255.

Curl SJ. 1994. Egyptomania - The Egyptian Revival:A Recurring Theme in the History of Taste. Manchester and New York: Manchester University Press.

Elliot Smith G, and Wood Jones F. 1910.Archaeological Survey of Nubia 1907-1908: Report on the Human Remains. Cairo: National Printing Department.

Lambert-Zazulak PI. 2000. The International Ancient Egyptian Mummy Tissue Bank at the Manchester Museum. Antiquity 74: 44-48.

Lambert-Zazulak PI, Rutherford P, and David AR. 2003. The International Ancient Egyptian Mummy Tissue Bank at the Manchester Museum as a resource for the paleoepidemiological study of schistosomiasis. World Archaeology 35(2): 223-240.

Rutherford P. 2000. The diagnosis of schistosomiasis in modern and ancient tissues by means of immunocytochemisry. Chungara Revista de Antropologia Chilena 32(I): I27-I3I.

Tapp E, Stanworth P, and Wildsmith K. 1984. The endoscope in mummy research. In: David R, and Tapp E, editors. Evidence Embalmed: Modern Medicine and the Mummies of Ancient Egypt. Manchester: Manchester University Press. P 65-77. 